\title{
Electricity as a Medium of Psychic Life Electrotechnological Adventures into Psychodiagnosis in Weimar Germany
}

\section{Cornelius Borck}

Institute for the History of Medicine, Center for Humanities and Health Sciences, Free University and Humboldt University Berlin

\section{Argument}

When electricity became a commodity in 1900, it furnished Germany with new attractions and revolutionized everyday life with all kinds of tools and gadgets; it also opened up a new space for investigating psycho-physical interaction, reviving ideas of a close linkage between psychic life and electricity. The paper traces the emergence of this electro-psychological framework beyond "electroencephalography," the recording of electrical brain waves, to "diagnoscopy," personality profiling by electric phrenology.

Diagnoscopy opens a window onto the scientific and public cultures of electricity and psychical processes in Weimar Germany. It garnered enormous attention in the press and was quickly taken up by several institutions for vocational guidance, because it offered a rapid and technological alternative to laborious psychological testing or "subjective" interviewing. Academic psychology and leading figures in brain research reacted with horror; forging counter measures which finally resulted in this technique being denounced as quackery. A few years later, the press celebrated electroencephalography as a mind-reading device, whereas the neuroscientists remained initially skeptical of its significance and the very possibility of an "electroencephalogram" (EEG) before they adapted electroencephalography as a tool for representing various neuro-psychiatric conditions in patterns of recorded signals. The blending of psychophysiology and electrical engineering marks the formation of an electric epistemology in scientific as well as public understanding of the psyche. The transformations of electrodiagnosis from diagnoscopy to the EEG are indicative of a cultural shift in which electricity changed its role from being the power source for experimental apparatuses to becoming a medium of psychic processes.

"Here in front of my eyes, in the graph with all its peaks and numbers, lay the line of my character. It was an image of my personality, almost identical to the one I am carrying in my heart" (Ludwig 1926, 301). The famous German writer Emil Ludwig was truly overwhelmed by the capability of a new electrical apparatus when he 
reported, in the popular weekly Berliner Illustrirte Zeitung on March 6, 1926, how the machine had revealed his own psychogram. "Diagnoscopy," as this method was called, determined a personality profile within minutes by electrically stimulating specific "reactions zones" on the surface of the head. Touching these zones with a detecting electrode closed an electric circuit and electric stimuli elicited a graded response in the form of a more-or-less loud tone. The loudness of the evoked responses at each stimulated spot indicated the individual's development of the psychical quality represented there. A full examination required a run through the full set of ca. 50 reaction zones, representing specific character traits, and revealed personality as the graphic profile of the individual expression of these traits (as detected at each individual spot). Ludwig celebrated the new device with the rhetorical skill of a successful writer, whose historical fictions and biographies had sold millions and been translated into many languages. ${ }^{1}$ To him, the construction of the little machine was a decisive step in the intellectual development of the still young twentieth century; and he traced for its inventor a genealogy of highest accolade in science as well as technology: "After Bunsen and Helmholtz, Edison and Marconi, Curie and Roentgen follows now the name of Zachar Bissky" (Ludwig 1926, 299). Ludwig's positioning of the machine in this peculiar blend of famous names, weaving together threads from the detection of rays and waves, from radio construction, and from the development of electrical communication devices, may reflect poetic license. However, he was not the only one to report on diagnoscopy: further reports appeared in the Vossische Zeitung, the Berliner Börsenkurier, or the Umschau. Adolf Friedländer, for example, a professor of neurology in Frankfurt/Main, praised the electrical machine in the widely read Frankfurter Zeitung. The press typically glorified diagnoscopy as a new visualizing tool and characterized it as an x-ray machine of the soul. ${ }^{2}$

In addition to arousing public interest, diagnoscopy kindled widespread scientific scrutiny and practical applications, mainly for vocational guidance, thereby securing the electric tool a meteoric career in Weimar Germany. Scientific investigations with this technique were conducted in Stuttgart, Karlsruhe, Bruchsal, and Berlin; supporters came from philosophy, psychology, engineering, medicine, and geology. Provoked by the stormy reception and infuriated about what they judged to be diagnoscopy's unsound principles, leading figures from academic psychology, physics,

\footnotetext{
${ }^{1}$ Horckheimer and Adorno referred to him, along with Hemingway, in identifying what they branded “enlightenment as mass deception" (Adorno 1996, 165). Emil Ludwig (1881-1948) started as a war-journalist during World War I for the Berliner Tageblatt and became famous during the 1920s for biographies on Goethe, Napoleon, and Wilhelm II. Being of Jewish origin, he took Swiss citizenship in 1932, before the takeover of the National Socialists, and emigrated to the United States in 1940. Although heavily engaged in supportive activities for other émigrés, he continued writing historical biographies and publications on a vast list of historical figures, comprising, among others, Cleopatra, Jesus, Beethoven, Schliemann, Lincoln, Bolivar, Hindenburg, Masaryk, Stalin, and Mussolini. On Ludwig see Mosse (1992) und Gradmann (1993).

2 The Berliner Börsenkurier, May 5, 1926, for example, entitled its report: "Radio-illumination of the soul;" Ludwig (1926, 306) concluded his article similarly: "Roentgen visualized the concrete entities from the interior of the body, Bissky the abstract."
} 
and brain research reacted strongly against what they saw as a threat to scientific standards. The instrument's celebrity finally called into action the Tenth Congress for Experimental Psychology, the Kaiser Wilhelm Society (one of the leading funding organizations for science in Germany), OskarVogt (the director of the brain research institute of that society), Georg Graf von Arco (the technical director of Germany's leading radio company Telefunken), among others, in various efforts to forge counter measures. Whether or not it was due to these activities, the little gadget failed to maintain its frail position in a network of popular culture, electrical engineering, psychological testing, and scientific investigation. It fell into oblivion in the following years, and with it the name of its inventor, Zachar Bissky. In 1929, however, memory was still fresh, and when Hans Berger published what he called the human electroencephalogram (EEG), the recording of electrical brain waves from a human head, the popular press drew close parallels to Bissky's diagnoscopy, celebrating the new device as a mind-reading machine. ${ }^{3}$ Berger himself felt obliged to mention Bissky, although in a critical tone. Apparently, the two techniques, diagnoscopy and electroencephalography, operated in an overlapping cultural space. They were both part and parcel of a broader movement toward electric conceptualizations of psychic life in Weimar Germany. An analysis of diagnoscopy can help to illuminate the historical place of the EEG at the moment of its construction.

By elaborating on the network of actions diagnoscopy entailed, I argue that a form of electropsychology emerged out of psychophysiological investigations during the 1920s. Far more than being simply the power source for running experimental setups, electricity became a medium of psychic life in Weimar culture. The ambivalent attitude toward psychophysiology in Weimar Germany has recently been reassessed by Mitchell Ash (1995) and Anne Harrington (1996), among others (Lawrence and Weisz 1998) along the modernism/holism divide. Characteristic of the form of psychological electrodiagnosis presented here is, instead, a blending of psychology with technology and electrical engineering, manifesting a syncretism of "modern" and "traditional" strategies. This syncretism and the underlying hybridization of psychophysiology with technology drew on the dramatic changes resulting from the electrification of households and everyday life, which have been the object of many studies (Giedion 1969; Hughes 1983; Beltran 1991; Nolan 1994; Osietzki 1996; Goldstein 1997; Plitzner 1998; Binder 1999). Psychophysiology in Weimar Germany blurred the distinction between science and technology as well as that between holism and modernism or that between science and unorthodox activities.

\section{Cultures of Bioelectricity in Weimar Germany}

The symbiosis of technology, the human body, and psychic life, as it emerged during the 1920 s in the specific historical constellation of Weimar Germany may be

\footnotetext{
${ }^{3}$ One article (Gradenwitz 1930) even saw in Berger's EEG the ultimate confirmation of Bissky's approach.
} 
illuminated by the illustrations in Fritz Kahn's popular anatomy Das Leben des Menschen (Kahn 1929). ${ }^{4}$ The imaginative and compelling drawings depict the functional organization of the human body, throughout the five volumes, as "modern" technological systems. This strategy was certainly not new; conceptualizing organs and body functions by means of advanced technologies was a continuing strand in the tradition of neurophysiological research and of its popularization. ${ }^{5} \mathrm{Kahn}$, however, did more than simply apply this explanatory strategy as a rhetorical figure; he depicted the physiology of the human body as a cultural product. His visualizations typically demonstrate the interdependence of physiology and technology as a form of common experience in the daily life of ordinary people from the period. The drawings style psychophysiology as an electrically mediated form of modern life in the 1920s. A particularly striking example is Kahn's visualization of the sensory nervous system as a radio set up, in which the sensory cells equal the antenna; the wire, the neuron; the machine transforming the electromagnetic into acoustic waves, the nervous center in the brain stem; and the headphones, the conscious act in the cortical cells (fig. 1). This is the typical script of machine metaphors, but the picture elaborates it as a night view of a corner in a modern city with tall buildings and heavy traffic in the electrically lit streets. While the radio equipment is depicted as being in use by somebody in the top floor of the tallest house, the sketch of the human physiology has turned into an oversized advertisement hanging on the wall of the opposing building over several stores. The psychophysiology is centered on this symbiosis of technology, culture, and body practice. In the reading of this visualization from the late 1920s, picking up electromagnetic signals, tuning in the radio, listening and experiencing sound, sensing impressions, processing nervous signals, and expressing feelings have become insolubly intertwined in a "modern" way of city life.

Allied with the public interest in new electric technology and its physiological significance, as demonstrated in Kahn's popular neurophysiology, therapeutic applications of electric currents flourished throughout the 1920 s in a broad variety of forms. Electrotherapy, well established in Europe and in the United States since the

\footnotetext{
${ }^{4}$ Kahn made a career as a great popularizer of human physiology and anatomy by developing a personal style of fusing medical knowledge with modern life, in all its technical manifestations. With this combination of rhetoric and visualization, he resembled in some ways Ernst Haeckel, but instead of serving the German Bildungsbürgertum's longings for an aesthetic and holistic concept of nature in the nineteenth century, Kahn addressed the educated masses of the 1920s for adapting them to a life in a technoscientific world. For a more detailed analysis of Kahn's popularization of neurophysiology, see Borck 2001.

${ }^{5}$ Throughout the nineteenth century, the nervous system has been compared with, explained by, and investigated as a biological telegraphy system. And telegraphy was, respectively, understood as a system of messages and commands, traveling between a periphery and a brain-like center. The analogy between telegraphy and the nervous system had already served Ernst Kapp (1877) as evidence for his conceptualization of technology as a materialization of organic principles. More recently, Marshall McLuhan postulated media in general to be body extensions, an idea somewhat reminiscent of Kapp's concept (McLuhan 1964). In the history of science, Lenoir (1994), Kittler (1992), for example, explored exchanges between technological and physiological developments without Kapp's teleological framework.
} 


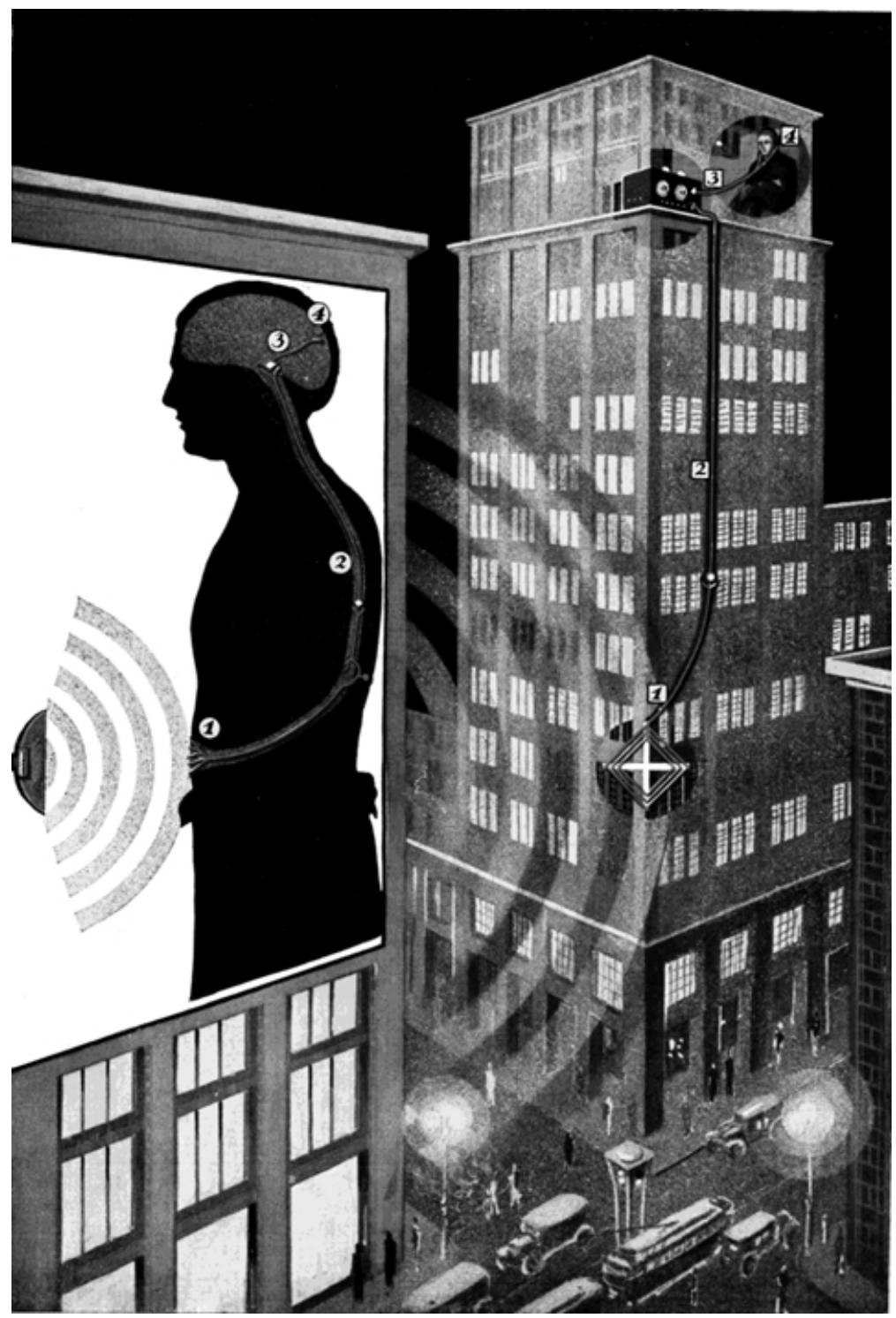

Fig. 1. Neurophysiology as the product of media culture: Fritz Kahn's depiction of the sensory nerve resembling a radio set. From: Fritz Kahn. 1929. Das Leben des Menschen. Volume 4, table VII. Stuttgart : Franck'sche Verlagshandlung.

end of the eighteenth century but under constant pressures to redefine its institutional space (Rowbottom and Susskind 1984; Rosner 1988; Morus 1998; Gernet and Habrich 2000; Pancaldi and Bertucci 2001), benefited, in the twentieth century, from the installation of a general electric power supply. Plug-in devices revolutionized this 
practice as a form of physical therapy, both in hospitals and in private practice (Berliner, Laqueur and Tobias 1926; Hubenstorf 1993). ${ }^{6}$ Alongside this professional market, various companies specialized in manufacturing small-scale apparatus for home treatment by the lay public. Some of these companies were enormously successful, supplying a large proportion of Germany's private households with some form of electrotherapeutic device. ${ }^{7}$ In these practices, the therapeutic application of electric currents was usually embraced as a panacea, as a kind of general treatment resulting in a "re-vitalization" of the human body, recharging the "batteries of life" (Asendorf 1993). The list of symptoms and diseases recommended here for electric therapy was long and non-specific; it ran from all forms of nervousness to paralysis, fatigue, or pain. ${ }^{8}$

In neurophysiology, in contrast, research in 1920s focused on localized or isolated nervous activity, where the newly developed technologies of vacuum-tube amplification and cathode-ray oscillography (Gasser and Erlanger 1922) allowed physiologists to display the activities of individual nerve fibers. ${ }^{9}$ This technique enabled them to dissect the communication between muscle and nerve, and within nerve fibers, down to the level of individual signals, and pushed research in neurophysiology heavily towards micro-analysis (Frank 1994). With this shift in full swing, recording brain waves, the summarized activity of thousands of neurons, did not feature among the favorable research topics in the leading neurophysiological labs (Smith 2001). Throughout the first three decades of the twentieth century, physiologists did not search for electric activity in the human head. Several specialized laboratories in Europe and the United States had all the equipment necessary for recording an EEG, but no such attempts were made in any of these labs before Berger's publication. Work on reflex arcs and on the functional organization of the nervous system had converged in the identification of a fast and monotonous signaling code, almost identical for every nervous structure investigated, which operated on the basis of spatio-temporal specificity. In this framework, recording electrical potentials from the brain, let alone the surface of the head, was apparently regarded as meaningless, probably because of an expected cacophony of myriad

\footnotetext{
${ }^{6}$ The 1931 catalog of the leading German manufacturer of electro-medical apparatus, Siemens, for example, listed electrotherapeutic gadgets on more than 40 pages (Katalog E 30: "Apparate und Instrumente für Elektrodiagnostik, Elektrotherapie, Massage u. Chirurgie,” Siemens Medical Engineering Archives Erlangen. I thank Doris-Maria Vittinghoff for making this material available to me).

${ }^{7}$ The Wohlmuth AG distributed its devices for high-frequency therapy so widely, that its manual (Wohlmuth 1925) ran through ten editions in five years (plus several translations) and interferences with radio transmission became a common problem (see Möhringer 1927).

${ }^{8}$ The contemporary literature on medical electricity is vast. A typical example from the German context is Cohn (1898) which was printed in 7 editions until 1927. For a historical analysis of the relation between electrotherapy and neurology, see Senior 1994.

${ }^{9}$ For the history of electrophysiology and neurophyisology in the nineteenth century, see Brazier 1959, 1988.
} 
signals resulting in noise. ${ }^{10}$ Nonetheless, placing electrodes on exposed human brains was quite famous a practice in Germany at that time, but in a different context. The neurosurgeon Otfrid Foerster from Breslau, then one of the most eminent scientists in his field, applied electric currents during neurosurgical operations in order to determine the cortical localization of functional centers in the human brain (Foerster 1926). Instead of recording electrical activity, he observed the responses to localized electric stimuli in various anatomically defined cortical areas during surgery for epileptic lesions and other brain diseases. ${ }^{11}$ In Foerster's line of research, as well as in electrodiagnosis in contemporaneous academic neurology, electrophysiological investigations centered around the organic, elucidating the topographical and functional organization of the nervous system (Steinhausen 1928). The neuroscientists at the universities limited their investigations, very much in contrast to the flourishing culture of popular theories about electro-psychological interactions, to the biological.

\section{Electro-phrenology: the Tingling Sound of the Psyche amidst the Rationalization of Life and Labor}

Ludwig described Zachar Bissky's practice of diagnoscopy in such rich detail that his text from the popular press provides one of the best available sources, although he neglected some technicalities (such as specifications on the electrical apparatus). ${ }^{12}$

In an empty room anywhere in Berlin, I am guided towards a medium sized, square case of metal, which contains, as I am shown, an accumulator, a rheostat, and a switch. Next to it on a table stands a plaster head, full with many red and black numbers . . . Firstly, by grasping one of the electrodes with both my hands, the voltage level which I can take without pain or shock is being determined in less than a minute .... I next get one of the telephone receivers placed on my head... The experimenter then closes in with the second electrode, ending in a thin rod, on my head and touches it precisely on the spot which corresponds to point number 1 on the plaster head. I do not know yet what 1 is. Now the investigation runs quickly from point to point: With each touch I hear with my

\footnotetext{
${ }^{10}$ At the end of the nineteenth century, however, the electrical activity of cortical neurons had been on the agenda in neurophysiology. In 1875, Richard Caton of Liverpool published a preliminary report on the electrical activity of the brain, and around 1890, a group of three to five physiologists had a priority dispute on the topic (Brazier 1961; Borck 2000). At the beginning of the twentieth century, the Ukrainian physiologistVladimir Pravdich-Neminsky was one of the very few to pursue this line of research. He recorded electrical activity from the exposed brains of various vertebrates and published the so-called "electrocerebrogram" of the vertebrate's brain in 1925 (Prawdicz-Neminski 1925).

${ }_{11}$ As late as 1935, Foerster's group engaged in recording electric activity from the exposed human brain (Foerster and Altenburger 1935).

${ }^{12}$ The engineer Hinrich Ott (in Bissky 1925, 35-38) described the currents produced by Bissky's apparatus as a special form of alternating current generated by an industrially manufactured battery in an interrupter circuit. Bissky apparently experimented with currents of various frequencies (from 18 to $672 \mathrm{~Hz}$ ) but finally recommended $335 \mathrm{~Hz}$ as the frequency coinciding with the rhythm of the brain itself, see below.
} 
earphones a more silent or louder tone, a cheeping, similar to the one indicating an engaged line in telephone communication. A scale of four levels of loudness has been explained to me beforehand, enabling me to now control the experiment .... The form in front of the secretary, prepared with a list of the points soon fills up with values between 1 and $4 \ldots$ After completion of the investigation in less than half an hour, I took the sheet with an excitement beyond curiosity, and looked at the winding line, similar to a temperature or weather curve, which resulted by connecting the individual values in the scale from 1 to 4 at each point. I juxtaposed to this charade a legend in form of an explication of each point in psychical terms .... I read how fantasy and logic, how constructive thinking, color sense and orientation, mathematics and techniques are represented in myself in degrees of normal, less, or more than normal. I read whether volition and determination, mysticism or neurasthenia, idleness, stinginess, parsimony, selfishness, sexuality, violent temper, diligence, accuracy, eagerness, velocity of thinking and acting were weak or strong in me. (Ludwig 1926, 299-301)

Where Ludwig experienced the fulfillment of highest promise by means of electrical technology, others saw the dubious revival of a quack science. Indeed, diagnoscopy resembled in many ways Franz Joseph Gall's phrenological practice as it existed for more than a century. ${ }^{13}$ In both systems, psychological faculties were conceptualized as sets of topographically arranged factors that mapped surface details of the head. Several dozen identified psychological qualities corresponded to precisely localized spots or regions on the surface of the head, thereby prefiguring and mirroring the localizing of bodily and mental functions in the brain which began to dominate the neurosciences in the second half of the nineteenth century. With both techniques, phrenology and diagnoscopy, individual psychical qualities were determined by comparing signs from a head under investigation to a standard model. In phrenology, particular protrusions of the skull indicated the development of underlying brain centers; in diagnoscopy, the responses to the application of pulsating currents were taken as representations of psychic qualities. Like phrenology, diagnoscopy provided a psychological profile in the form of a list of scaled factors of personality such as will, eagerness, diligence, selfishness, etc. It is hardly surprising, therefore, that diagnoscopy was quickly criticized as too close an analog to a phrenology of the Gall type. One reviewer meticulously compared Bissky's with Gall's system and noted correspondences in most of the conceptualized psychological faculties, and perfect matches in more than a third of the assigned spots (Walter 1927). According to this critique, Bissky had only reshuffled the numbers and reordered the faculties to a new psychological system, but without significantly altering the basic set of concepts. The similarities to phrenology notwithstanding, diagnoscopy displayed several distinctive features: First of all, the application of electricity turned Gall's anatomical examination of the skull into a functional test of the living organ inside. Diagnoscopy

\footnotetext{
${ }^{13}$ There is ample literature on the history of phrenology; a good introduction is Young (1990); for an investigation of phrenology's space in the borderland between science and the public, see Cooter 1984. On Gall's influence on the "cerebralization" of man, see Hagner 1997.
} 
thus distanced itself from static physical factors such as Gall's protrusions by stipulating complex but yet unspecified functional links between brain centers and response zones. Part of this more dynamic and flexible approach was also a biographical interpretation of the reactions at symmetric points on left and right brain spots as inherited (right) vs. acquired (left). ${ }^{14}$ Another important difference was Bissky's allencompassing approach, compared to Gall's exclusively psychological system: There were two systems of points on his plaster head (Ludwig's red and black numbers), one for a set of 25 organic correspondences, and the other for a set of at least 50 psychical correspondences, allowing for a combination of psycho- and body-analysis. Of the two, the psychic side aroused much more interest, whereas the organic drifted in calmer waters. ${ }^{15}$ Biographical information on Bissky is scarce: He was referred to as a physician from Ukraine, born in Proskurow in 1885, whose book on diagnoscopy was first translated into French and from that into German (Friedrich Mißmahl, in Bissky 1925, 4). Apparently he practiced his method in Poland and France, before he came to Germany - if his move was the result of being persecuted in the other countries as his critics claimed, this can not be proved (Baumgarten 1926). In Germany, diagnoscopy made broad public appearance in 1925. In January, Wilhelm Paulcke, professor of geology, arranged a three-day meeting on Bissky's method at the Technical University in Karlsruhe. ${ }^{16}$ By then, diagnoscopy had already been recommended for personality testing by a Swiss organization for the rationalization of labor and was introduced by the Swiss postal services and the clock-manufacturing school of Geneva (Paulcke 1925). Over the same year and thanks to Paulcke's conference, this list of institutions employing diagnoscopy grew much longer, including Technische Hochschule Karlsruhe, Technische Hochschule Stuttgart, Preußische Hochschule für Leibesübungen, Hauptprüfstelle für Sport und Berufskunde Berlin, Kriminalpolizei und Schutzpolizei Berlin, Landeszuchthaus Bruchsal, Maschinenbau-Gesellschaft Karlsruhe, Gelsenkirchener Bergwerks-AG. ${ }^{17}$ In most of these places, diagnoscopy was employed in vocational guidance. At the Burchsal state prison, a preliminary forensic investigation was performed by diagnoscopic testing (Paulcke 1925; Friedländer 1926). And the professor of philosophy of the University of Bonn, Johannes Verweyen, recommended diagno-

\footnotetext{
${ }^{14}$ Apparently, Bissky had merged the traditional differentiation between good and bad along the right-left axis with his new dichotomy of inherited-acquired; in other cases, he described right and left as on vs. off, see below. For the history of organizing the brain in dichotomic oppositions, see Harrington 1987.

${ }^{15}$ But at least the German physician Richard Rahner employed diagnoscopy as a medical test. In January 1926, he demonstrated the method to the professors of internal medicine and pioneers of electrocardiography, Friedrich Kraus and Hans Friedenthal at the Charité Hospital in Berlin (Rahner 1926). Rahner also fought a priority dispute about his medical diagnosis with Bissky, arguing that he had started with observations in this direction as early as 1906.

${ }^{16}$ Paulcke was an ardent alpinist and had organized the German and Turkish mountain infantry during World War I where he may have become interested in personality testing and personnel selection.

${ }^{17}$ According to Walter $(1927,306)$. The number of active supporters was probably smaller, since some of these places can be traced back to the activities of one and the same person; all institutions listed for Berlin, for example, relate to Robert Werner Schulte's various places of work.
} 
scopy for marriage counseling and eugenic purposes (J. M. Verweyen, quoted in Arco and Herzberg 1927, 12; see also Verweyen 1926).

Still in 1925, Bissky published a book on diagnoscopy, advertising, in the subtitle, his method "for medical, psychological, and forensic diagnosis." This book combined letters of recommendation and extracts from scientific investigations by others with a series of more speculative chapters by Bissky in which he described the background and practice of his method. ${ }^{18}$ He legitimized his technique as entirely empirical and crafted the following story of invention:

After a long series of laborious investigations and experiments over several years, I succeeded in finding a specific form of alternating current by the use of which I could always elicit or alleviate [my migraine] by applying the current to the painful spots on my head. My original supposition about the connection between electricity and pain in the brain was confirmed. I had discovered the physiological rhythm of our nervous system and that enabled me to construct an apparatus producing alternating current with a frequency corresponding that of the brain. (Bissky 1925, 16)

And he did not shy away from extending the possibilities of his method into the fantastic:

If we narrow the electrode with the blue cable of my special reflex apparatus to the spot 1 [related to speech] on the left side of the head, the subject will get more lively and engage in talking ever faster until the words come out tumbling and finally the muscles of speech move too fast for producing any distinct words. But if we touch the spot on the right side of the head the subject will calm down and get back to normal .... Another example: We have a subject of ideal calm and gentle character. We now touch the spot 43 (malice) with the electrode with the red cable and have to experience how the person gets angry more and more and becomes intolerable. If we touch the spot with the blue cable, the storm passes and the old, sympathetic, good-willing human being sits in front of us. (Ibid., 21-23) $)^{19}$

Such fantastic statements notwithstanding, Bissky did quickly find support from scientific psychology. Fritz Giese and Robert Werner Schulte, two young pioneers of

\footnotetext{
${ }^{18}$ Bissky added some hint about an imminent perfection of the method by transferring to it the application of electromagnetic rays instead of currents; and it is indeed highly likely that his method later took this turn. The only other publication by Bissky, apart from his booklet on diagnoscopy, I was able to trace (in the Bakken Library of Electricity in Life in Minneapolis, thanks to Elizabeth Ihrig), was a small booklet of a radiological institute at Paris named "Centre de bioradioscopie de Bissky," from 1935, advertising a form of radio-diagnosis.

${ }^{19}$ It is hard to imagine how statements such as these could have gained Bissky acceptance from the scientific community, and indeed, there is no other reference in the literature to, for example, the adverse effects of the two different electrodes.
} 
psychotechnics, i.e. vocational guidance by means of aptitude tests, embarked on a scientific investigation of diagnoscopy in 1924, apparently independent of each other. Giese reported first results with diagnoscopic personality testing to the Ninth Congress of Experimental Psychology in Munich, in April, and Schulte published a research paper in October 1925 (Giese 1926; Schulte 1925). Both left aside the whole issue of whether such a form of psycho-diagnosis would make sense in terms of neurophysiological theory, but applied it, instead, empirically in their field of specialization. ${ }^{20}$ They simply put to the test Bissky's promise: "Diagnoscopy saves a maximum of social, intellectual and psychical energy from being wasted and allows to bring it into efficient usage" (Bissky 1925, 29). And they both gained highly promising results; Giese found a mismatch of diagnoscopy with personality profiles from interviews of only 15 per cent, provoking stormy discussions at the Munichmeeting of experimental psychologists, and Schulte calculated a positive correlation of 86.3 per cent. These young psychologists envisioned psychotechnics as an economically beneficial and individually rewarding form of counseling, providing for the rationalization of life and labor on a national scale. They praised diagnoscopy as perfect means for their high hopes. According to their conclusions, diagnoscopy revealed personality profiles with sufficient reliability in a fraction of the time required for established methods such as aptitude tests and psychological interviews. ${ }^{21}$

Psychotechnics started in Germany with Hugo Münsterberg's book of that title in 1914 as a branch of applied psychology, deeply interwoven with the organizational needs of the nation at war. After Germany's defeat, the re-organization and modernization of the economic sector earned psychotechnics new fields of responsibility. ${ }^{22}$ Psychotechnics was proclaimed as a socially balanced form of distributing the work force to the jobs, optimizing - in contrast to the allegedly purely economic labor-rationalization of Taylorism - for economic as well as for individual needs, like training, adaptation, abilities, gender, skills, etc. (Baumgarten 1928; Burrichter 1983; Jaeger 1985; Hughes 1989; Rabinbach 1990). Particularly in

\footnotetext{
${ }^{20}$ Schulte explicitly rejected any physiological conceptualization as speculative: "The question, if there are any detectable connections between the operations of the central nervous system, especially the cortex, and the peripheral skin regions on the head (one could think of trophical, tonical, electrical - especially ray-mediated -, or minute chemo-biologial influences), remains for the moment hypothetical, any investigation in that direction would currently be of crudest and utopian materiality" (Schulte 1925, 78).

${ }^{21}$ Employment counseling had already in the nineteenth century been stressed as one of the appropriate uses of phrenological testing, and was, at least in the United States, part of its successful popularization. Later, and almost coinciding with Bissky's method, an electromechanical phrenology-machine made its appearance in the United States, which automatically revealed the significance of the protrusions of the skull by means of dozens of electrical contacts in a helmet-like head gear and which finally became a coin-operated automaton for public entertainment (Risse 1976).

${ }^{22}$ German psychology journals opened their pages to psychotechnics, and new ones in this field, such as Industrielle Psychotechnik, started soon after the end of World War I. Technical universities in particular began employing professors for psychotechnics or applied psychology; the first was Walter Moede at the Technical University Berlin-Charlottenburg in 1921.
} 
Germany, psychotechnics was a concerted action of companies seeking the image of a modern, rational, and therefore humane corporation; of governmental agencies like the ministry of labor or local employment offices experimenting with new forms of rational planning; of scientists, especially from applied psychology, but also from physiology, medicine, and economy, expanding into new careers (Hinrichs and Peters 1976; Sachse 1987).

The careers of Giese and Schulte very much reflected the heterogeneity of this field where academic psychology interconnected with the society at large. Born in the last decade of the nineteenth century, they both studied with Wilhelm Wundt at Leipzig, Giese before and Schulte during World War I. After finishing university studies, they created small institutes for applied psychology, Giese in Halle, Schulte in Berlin-Spandau, and started lecturing on psychotechnics for various audiences via all available media: the press, radio, film, public seminars, and exhibitions (as part of the GESOLEI in Düsseldorf 1926, for example, and the International Hygiene Exhibition in Dresden 1930). Not a single occupation proved unworthy of a thorough scientific investigation into the required skills, mental profiles, or body movements. From women's hairdressers to modern traffic, from the quarry industry to stenotype, there was hardly any field of applied psychology these entrepreneurs and popularizers of psychotechnics did not deal with. Likewise, they shared wide-ranging interests beyond psychotechnics, from occultism to body culture and literature. Giese's first book was an essay on yet unknown thought waves; Schulte investigated parapsychological practices (Giese 1910; Schulte 1925/26). Both engaged in developing sports psychology in Germany. Schulte wrote poems and novels, and adventured into parachuting and flying (Schulte 1926, 1928). Giese published in 1925, the year of his work on diagnoscopy, Girlkultur, a book-length comparative analysis of American and German culture. Their academic careers, in contrast, were rather different. Giese gained a professorship at the Technical University of Stuttgart in 1923 and quickly supervised a wide-ranging network of cooperators for his multivolume Handbuch der Arbeitswissenschaft (Giese 1925-34). Schulte, although he was Walther Moede's first assistant at one of the founding centers of psychotechnics in Germany in the Technical University in Berlin-Charlottenburg, had problems with entering the academic establishment. He directed various private departments and institutes for applied psychology, started a journal of applied psychology (Psychologie und Medizin), and advised several branches of public administration, but he never got a full academic position or professorship. Both died young, Giese in 1935 at age 45, Schulte, ten years younger, in January $1933 .{ }^{23}$

\footnotetext{
${ }^{23}$ Giese died accidentally at a medical operation in preparation for a career as an SS officer (Stefan Petri, personal communication). Schulte took his life after his marriage fell to pieces within weeks after a friend of his crashed his newly bought plane into the river Danube, ruining Schulte's personal wealth and jeopardizing plans for a joint excursion to Africa. He took his life with the skills of an experimental psychologist by combining sleeping pills with a purpose-built time fuse for a controlled gas explosion in his laboratory (Lück 1994; Lück and Rechtien 1994).
} 


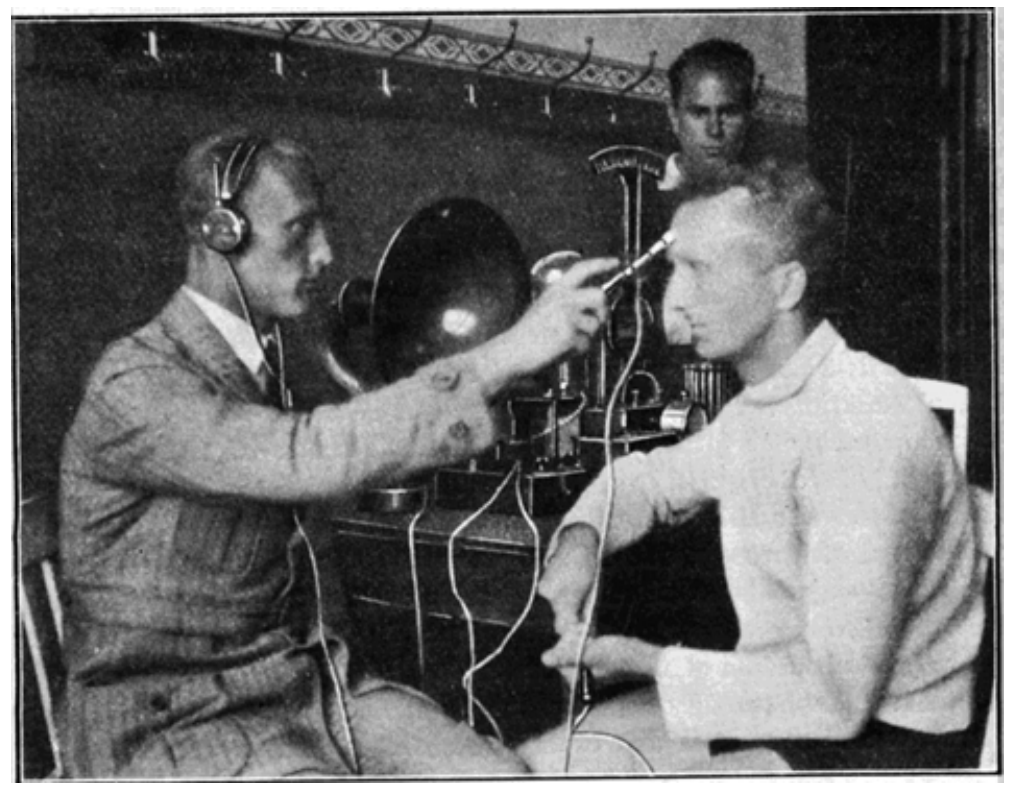

Fig. 2. Diagnoscopy with electrode rod and acoustic control. From: R. W. Schulte. 1925. "Über Elektrodiagnose seelischer Eigenschaften." Psychologie und Medizin 1:77.

Giese and Schulte were both present at Paulcke's meeting in January 1925 in Karlsruhe. There Schulte presented the first results of his investigations on diagnoscopy, for which he was awarded funding by the Deutsche Forschungsgemeinschaft. ${ }^{24}$ Three months later, in April 1925, Giese reported on 50 diagnoscopic examinations at the Ninth Congress of Experimental Psychology at Munich (Giese 1926). In October 1925, a full report by Schulte, based on more than 300 tested cases, appeared in the opening issue of his journal Psychologie und Medizin. Here, Schulte concluded that the accuracy of diagnoscopy matched that of other experimental procedures in psychotechnics "with an average level of validity" (Schulte 1925, 85). Graphical illustrations abounded in this paper, altogether more than 30 graphs and tables in a total of 32 pages. Many of them were labeled "statistical evaluations" and showed graphical visualizations of the almost perfect match between diagnoscopic results and Schulte's standard, i.e. the established methods of psychotechnics. Additionally, Schulte included diagrams of the electric circuitry and several photographs of the experimental procedures (fig. 2). He thus shaped an image of

\footnotetext{
${ }^{24}$ According to Schulte (1925); unfortunately, there is no file related to Robert Werner Schulte among the archival material from the Deutsche Forschungsgemeinschaft at the Bundesarchiv. Schulte almost certainly knew of diagnoscopy since 1921, when Bissky first demonstrated (apparently without success or public notice) his method in Moede's laboratory. The relation between Bissky and Schulte is not entirely clear, but there certainly was some form of cooperation, since an abstract of Schulte's paper was included in Bissky 1925.
} 
objectivity for diagnoscopy by constructing a context of scientific evaluation. ${ }^{25}$ "All subjectivity is gone, number reigns"; Ludwig (1926, 304) had already praised diagnoscopy's impressive objectivity as purely quantitative method of testing, which left everything to the electrical machine and the graphic mode of representation. ${ }^{26}$ Schulte advanced this construction of objectivity one step further by situating diagnoscopy in the context of experimental psychology and by providing it a statistical evaluation. The criticisms against diagnoscopy in 1926/27 were special efforts to disparage the scientificity of Schulte's work.

Here are a few coordinates along the further trajectory of diagnoscopy, after Giese's and Schulte's positive papers in 1925: On March 17, 1926, the secretary of the Kaiser Wilhelm Society sent Friedländer's celebratory article in the Frankfurter Zeitung to OskarVogt, director of the Kaiser Wilhelm Institute for Brain Research, and asked for a response. ${ }^{27} \mathrm{~A}$ few months later, Oskar Vogt was again approached on this issue, this time by the pioneer of wireless telegraphy and technical director of the leading German company of radio technology Georg von Arco, who asked for secret cooperation in destroying Bissky's reputation. Arco had lectured, together with the neurologist and psychologist Alexander Herzberg, at Albert Moll's philosophical society in Berlin on May 6, 1926, on the "humbug" of the whole Bissky story. Since such a single lecture proved not enough to stop the affair, and since further celebratory newspaper articles pressed him to take further action, he thought of Vogt. At that stage, the issue had become delicate and required secret measures: Bissky's Bios-Institut für praktische Menschführung was unwilling to give away one of its machines into the hands of Arco or Herzberg, and Vogt feared his or his institute's name being publicly attached to diagnoscopy. They agreed to secretly send one of the institute's not-so-well-known fellows to borrow an apparatus. ${ }^{28}$ Others joined forces. The First Congress of Psychotherapy, in 1926 in Baden-Baden, established a commission to evaluate the electrodiagnostic methods of Bissky and Rahner (the clinician using Bissky's method for the diagnosis of organic diseases). And Robert Sommer, the appointed chair of that commission, reported the entirely negative results of his investigation to the Tenth Congress of Experimental Psychology in the

\footnotetext{
${ }^{25}$ With the careful documentation of the protocols (for which Schulte used specifically designed and carefully printed forms) and with the multitude of evaluative graphs and tables, the paper created its own image of objectivity, besides that constructed for diagnoscopy, reminiscent of the statistical type of objectivity according to Daston and Galison 1992 (see also Galison 1998).

${ }^{26}$ The presentation of the results by means of the graphic method may well be Schulte's contribution to diagnoscopy, since Bissky initially experimented with touching a finger at the reactions zones and with detecting the response as an itching sensation. On the role of the graphic method in the shaping of physiology and in establishing its standards of objectivity, see de Chadarevian 1993 and Robert Brain 1996.

${ }^{27}$ Letter in the Cécile und OskarVogt Archiv, Düsseldorf, 34C. There is no responding letter by Vogt. For this and the following letters from the Vogt-Archiv, I thank Prof. Adolf Hopf and Ursula Grell for making the material available to me.

${ }^{28}$ Arco to Vogt, July 15, 1926, Vogt to Arco, July 16, 1926, and Rose to Arco August 18, 1926, Cécile und OskarVogt Archiv, Düsseldorf, 91A. The selected secret agent was Maximilian Rose, later founder of cerebral cytoarchitectonis in Poland, but apparently, these plans never materialized.
} 
following year (Sommer 1928). The physician turned writer Gottfried Benn characterized the period poignantly. "A hundred years of age, the achievement of three generations, modern medicine has run into crisis. [. . .] Psycho-physiognomy, Gall redivivus renew their systems. The university faculty flares up in dispute." (Benn [1926] 1985, 111)

The effects of this critical debate on the public reception of diagnoscopy and of Bissky's further activities would be difficult to estimate. Indicative traces are the more negative turn the press took later in 1926, with Adolf Friedländer revoking his earlier positive assessment in December (Friedländer 1926), and further critical comments, like Walter's comparison of Bissky and Gall, published in 1927. However, the issue lingered on and OskarVogt received another letter in May 1928. Now, the economist and emeritus director of the state office for employment of the Rhine province, Karl Kumpmann, wanted to introduce to him Dr. Missmahl, one of Zachar Bissky's cooperators. Again, vocational guidance and the multiple benefits the national economy might gain from such a simple and effective test concerned Kumpann. ${ }^{29}$ But it was too late and the battle was over without Vogt taking further action. His and others' activities had already sufficed to prevent Giese and Schulte from publishing on diagnoscopy more than once. And without further support from applied psychology, diagnoscopy did not manage to gain entrance into academic science anywhere else.

\section{The Secret Writings of the Brain: Hans Berger's Electroencephalogram}

Just four years after diagnoscopy's widespread press coverage, another electrical apparatus for psychic testing enjoyed a stormy reception by many newspapers, this time a mind-reading machine. The Neues Wiener Journal reported on July 4, 1930:

The scientists working with this apparatus are mind readers, they literally read the thoughts of the human guinea-pig with the silver electrodes in his head .... One imagine the wonder: There's a man sitting about doing some mental calculation, cables go from his head to a recorder in the room nearby in which there is nothing but the zigzag of the pen of the recording machine going over the paper. But nonetheless, the scientists read the moment the man starts his calculation, whether he exerts himself, and when he finishes. ${ }^{30}$ (Finkler 1930)

Again, an electric medium revealed the secrets of the psyche, but this time with the help of electrical recording equipment in the form of a moving line on photographic

\footnotetext{
${ }^{29}$ Kumpmann to Vogt on May 24, 1928, Cécile und OskarVogt Archiv, Düsseldorf, 33K.

${ }^{30}$ Slightly shortened versions of this article appeared one month later in the Stadt-Anzeiger Düsseldorf, in a newspaper in Hannover, and in the Neues Wiener Extrablatt. At least a dozen further papers reported on brain wave recording during the summer 1930.
} 
paper. The brain under scrutiny was literally writing its own activities onto paper. In October 1929, the leading German psychiatric journal, the Archiv für Psychiatrie und Nervenkrankheiten, had published an article by the director of the psychiatric clinic of the university hospital of Jena, Hans Berger, in which he presented the recording of a new electric voice of the human brain. In analogy to the human electrocardiogram, the writings of the human heart, Berger named the new trace "electroencephalogram" (EEG) and stated in this paper: "I therefore, indeed, believe that I have discovered the electroencephalogram of man and that I have published it here for the first time" (Berger 1929, 567)..$^{31}$

The publication of this paper has meanwhile been transformed into a historical moment that is regularly celebrated as the beginning of electroencephalography. But although Berger published his first report on the human EEG in the Archiv, it suffered a meager scientific reception over some years for various reasons. Perhaps the EEG's popular attraction fostered avoidance by Berger's psychiatric colleagues, because the scenario was too reminiscent of the Bissky episode. Perhaps Berger's reputation as one of the more isolated psychiatric clinicians with a well-known leaning towards speculative philosophy but lacking a proper training in electrophysiology kindled skepticism among neurophysiologists. Only after a group of young and aspiring scientists working at the Vogts' state-of-the art brain research institute at Berlin-Buch stepped in, did the tide turn. They presented in 1932 the "Neurograph," a high-tech instrument for recording brain waves that combined electronic amplification with ink-writing on endless paper and would set the standard for the next decades. Papers from this group at Berlin-Buch kindled the interest of Douglas Adrian in Cambridge, the doyen of neurophysiology at the time, who learned through them of Berger's original study and repeated Berger's experiments on his coworkers and himself. With Adrian touring the United States in 1934, and finally, with him presenting the EEG at the International Congress of Neurological Sciences in London in 1935, the scientific community accepted the existence of recordable electrical brain waves. More than five years after Berger's publication, the publication of the human EEG in 1929 was reconstructed as a historical moment. Douglas Adrian, honored with a Nobel Prize in 1932, convinced the scientific community of the feasibility of recording so regular a pattern of electric potentials simply by sticking electrodes to the human head.

Immediately afterwards, EEG groups spread all over the world, but especially in the United States (Brazier 1961; Richter 1981; Karbowski 1995). Eventually, even the group at Berlin-Buch, who initially concentrated its efforts entirely on animal research, started to record from human heads (Kornmüller 1938). Every translocation of the method to another place in this process involved dramatic transformations; and each experimental system acted more like a turning point in the history of electroencephalography, than like a step in a gradual development (Millett 2001;

${ }^{31}$ I cite Berger's reports from the English translation by Pierre Gloor $(1969,70)$. Berger suggested as the name for his trace "Elektrenkephalogramm." I follow Gloor in the general use of "electroencephalogram." 
Hayward 2001). ${ }^{32}$ Here, however, I confine myself to the experimental system at Jena, Hans Berger's very first publications on the human EEG, and the reception of the EEG in Germany before 1933. Instead of taking him as the starting point of an ongoing story, I want to reconstruct how he arrived at the EEG and how his work was situated in the context described so far.

Berger himself referred back to Bissky's diagnoscopy in his first EEG-paper (Berger $1929,567)$ and quoted his claim of a discovery of "the physiological rhythm of the central nervous system" (Bissky 1925, 16). But Berger did not share the entrepreneurial aims of the supporters of diagnoscopy. Compared to the inaugurated practical dimensions of diagnoscopy, Berger's EEG was the answer to his private way of philosophical theorizing. Most of his research projects line up as a life-long search for physiological concomitants of psychic processes, and of mental activity in particular. In this line of research, Berger subscribed to the graphic method (Chadarevian 1993; Brain 1996) and adhered to it throughout his life by extending it into new ways of graphical recording. The EEG ultimately proved to be the belated crowning stone of his research project, testifying to him the material and independent existence of psychic life. Berger's skills in the graphic method from his earlier studies enabled him to construct a method for recording the electrical signals of the human brain, although he lacked electrophysiological expertise. On the contrary, his lack of expertise in electrophysiology, in combination with his strong philosophical convictions about psycho-physiological connections, helped Berger to pursue his idea of recording electrical concomitants of mental activity, regardless of theoretical objections in ever new ways, and during many years of uncertainty, failure, and disappointment.

Berger spent his whole academic life at Jena, from his first days as a medical assistant until his retirement. ${ }^{33}$ After finishing studies of medicine at Jena in 1897, he entered the psychiatric clinic under Otto Binswanger and finally succeeded Binswanger in 1919. As director of the clinic, Berger was known for his strict regime - one of his assistants described him as "shy, reticent, and inhibited" (Ginzberg 1949, 370). He had married his laboratory assistant, Ursula von Bülow. She and their children, together with a few carefully selected patients and doctors from the clinic, acted as his most enduring and faithful volunteers in his studies. ${ }^{34}$ He retired in 1938, but suffered from depression and finally committed suicide in the university hospital of Jena in 1941, shortly after his $68^{\text {th }}$ birthday. Berger had the following poem by his

\footnotetext{
${ }^{32}$ This is one of the conclusions of my ongoing research project on the emergence of the electric brain; for preliminary results, see Millett and Borck 1999.

${ }^{33}$ For more biographical information see Boening (1941); Kolle (1956); Schulte (1959); and Wieczorek (1991).

${ }^{34}$ This division of labor, turning his subordinates and family members into "volunteers," was the only way of females entering electroencephalography in Jena. Although he took records of females, Berger did not conceptualize any difference in brain waves along gender lines, in contrast to, for example, Schulte and his various studies of gendered occupations.
} 
grandfather, the German poet Friedrich Rückert, hanging on the wall of his office and coining a motto to his life (quoted from Ginzberg 1949, 365):

Vor jedem steht ein Bild
Des, was er werden soll.
So lang er das nicht wird,
Ist nicht sein Friede voll. ${ }^{35}$

Initially Berger published on pathological anatomy, on neuropsychiatric cases and neurological observations. Since his habilitation at Jena under the guidance of his older colleague Theodor Ziehen, who later switched into philosophy and psychology, Berger showed a strong interest in psychophysiology. He approached this topic both experimentally and in lectures, so for example, by continuing the annual cycle of lectures on psychophysiology after Ziehen's move to Berlin (Berger 1921). He started experiments on psychophysiological relations by investigating the cerebral circulation, and his experimental projects were since based on the employment of graphical methods such as plethysmography, thermometry, and sphygmography. In his most extensive monograph, a four-volume book and atlas on the bodily manifestations of psychic states, he employed the well-established graphical method of plethysmography, i.e. the recording of volume changes, for correlating mental states with physiological signs (Berger 1904-1907). ${ }^{36}$ These recordings were characterized by a marked contrast between the exactitude of the measured changes and the uncertainty about underlying mechanisms. Whatever the plethysmographic charts showed, they were certainly not recordings of neuronal processes. However, the technique did offer evidence for psychological conclusions. The recorded traces contained information in the form of a correlation of purely graphical signs with particular states of mind, which could not be derived from an investigation of the processes involved in the generation of the traces. The correlative method skipped the intermediary steps and linked the observed states as assumed primary causes directly with the recorded signs, while omitting their (unknown) physiological mediation. Berger was thus well trained in handling, i.e. analyzing and interpreting, graphical records as purely semiotic systems before starting his electrical recordings. And he dealt with the EEG traces with an attitude developed in the use of these graphical instruments. To him, electroencephalography was another way of pursuing his long interest in psychophysiological recording. For Berger, electroencephalography validated his life-long search for the bodily manifestations of psychic processes, for the physiological concomitants of intellectual labor, as he concluded already in his first report:

\footnotetext{
35 "Each man faces an image / Of what he is meant to become. / As long as he does not achieve it, / He cannot attain his full measure of peace" (Transl. C. B.).

${ }^{36}$ In this study, Berger followed so closely the Danish psychologist Alfred Lehmann, that he even adopted the title from him. What Lehman had done with peripheral recordings from arm, leg and chest, Berger repeated by recording from the brain and head (Lehmann 1899, 1901).
} 
Is it possible to demonstrate the influence of intellectual work upon the human electroencephalogram, insofar as it has been reported here? Of course, one should not at first entertain too high hopes with regard to this, because mental work, as I explained elsewhere, adds only a small increment to the cortical work which is going on continuously and not only in the waking state. But it is entirely conceivable that this increment might be detectable in the electroencephalogram which accompanies the continuous activity of the brain. Naturally, I have performed numerous such experiments, but I did not arrive at an unequivocal answer. (Berger 1929, 569)

Within less than a year, Berger convinced himself of the regularity of the "influences of intellectual work upon the human EEG," although the observed correlation contradicted his expectations and perplexed him. ${ }^{37}$ Intellectual work, like sensory stimulation, appeared in the EEG as a typical switch from large, slow, and regular activity to small, fast, and irregular. Apparently a decrement of activity and a switching into noise-like scribbles signified the noblest operations of the brain. However, simply by looking at the writings of this new device - as the populace concluded from his article -, Berger could now observe whether the subject wired up to the machine was relaxed or engaged in any form of intellectual activity.

Berger's first efforts to experiment with the electrical activities of the brain date from the beginning of the twentieth century, but this remained a silent research activity, hidden from the public, including most of his assistant doctors (Ginzberg 1949; Kolle 1956). According to his own account of the discovery of the EEG, he achieved his first successful recordings in 1924 but worked for five more years on the corroboration of his trace before publishing it. Only after years of further laborious manipulation on body, mind, and machine in the isolation of the director's rooms of the psychiatric clinic at Jena which also served as a private laboratory, did the mind's signals as extracted from a human's head by Berger's machine prove stable enough to be imprinted and circulated among scientific audiences. Rather early on in this secluded research period, he privately described his aims as to construct a kind of cerebroscope ("Hirnspiegel"), an instrument recording but not reading psychic processes. ${ }^{38}$ He conceptualized the EEG as a device for documenting psychic processes via their physiological correlates but without deciphering the psychical or mental content of the recorded traces.

Berger was a modest man and so was his conception of the EEG as an analog to other visualizing devices in medicine; the cerebroscope dealt with the world of the psychological with particular discretion. Even after he began publishing on the EEG, Berger kept, in a certain sense, the psychic secret of the brain's writings. In a handbook article "On the physiological concomitants of psychical processes,"

\footnotetext{
37 "Es ist dies ein sehr merkwürdiges, von mir keineswegs erwartetes Ergebnis" (Berger 1930, 913).

38 "Möge es mir gelingen, den schon seit über 20 Jahren gehegten Plan zu verwirklichen u. so eben doch eine Art Hirnspiegel: das Electrenkephalogramm zu schaffen!” Diary, November 16, 1924. I quote from the diary clippings published in Jung 1963. Other valuable contributions regarding Berger's aims and background are Fischgold 1962; Schrenk 1970; Gloor 1974.
} 
published in 1937 but written before 1934, he characterized the EEG as an "immediate concomitant" (Berger 1937, 522; emphasis in original); the phrasing described with utmost precision what Berger aimed at. To him, the EEG recorded only the physiological side of psychic processes, and more immediacy was impossible. The EEG functioned as a gesture pointing towards psychic processes, proving their existence and their independence from other physiological processes. For Berger, the EEG trace was a phenomenon testifying to the material existence of psychic processes; but their secrets, being of different quality, could not to be found in the trace. To him, the EEG served its purpose entirely by providing evidence for the material existence of psychological phenomena.

The newspaper articles exploited the full imaginative potential of Berger's brain reading machine under titles such as: "The zigzag-line of the human soul"; "The electric script of thinking" etc., creating a stormy reception of the EEG in the popular press immediately after Berger had addressed a wider audience with a short article in the Medizinische Welt on June 28, 1930. ${ }^{39}$ In contrast to Berger's own discretion, the press did not share his hesitation and did not present the EEG as a discrete gesture toward the psychological, but rather as its deciphering. More than simply a means for recording brain activity, electricity had turned, according to these articles, into the language of the operating brain. Many of these articles included one and the same illustration, combining pieces snipped from Berger's records - an EEG, an ECG and time marks - into a single graph. The pictured recording typically included a part with an arrow and a mark "B" on it, indicating an inscription of meaning followed by an act of deciphering. But these traces and the markings were never described in any detail nor was their significance explained. Some added also a photo of Berger, resulting in an emblematic arrangement of the German inventor and his ingenuity in mastering the brain to write in black on white (fig. 3). The source for the grandiose titles and the seductive story pattern was obviously Berger's short remark on significant alterations in the EEG during sensory stimulation, mental arithmetic, or simply attention. However, the story sailed happily on its way without any technical underpinnings or details about the procedures of the test. After years of increasing use of the commodity of electricity and after various electric investigations into all forms of human psychic life, the time was ripe for revealing an identity of electricity and psychic activity. Or as one of the articles put it:

Today, the brain still writes secret signs. Tomorrow, we will probably be able to read neurological and psychiatric diseases in it. And the day after tomorrow, we will start to write our first honest letters in brainscript. (Finkler 1930)

\footnotetext{
${ }^{39}$ A first article by the same Adolf Friedländer who had also reported on Bissky's diagnoscopy appeared in the Frankfurter Zeitung in October 29, 1929, a few weeks after Berger's first report. A cascade of articles followed within weeks after Berger's summarizing paper in the Medizinische Welt.
} 

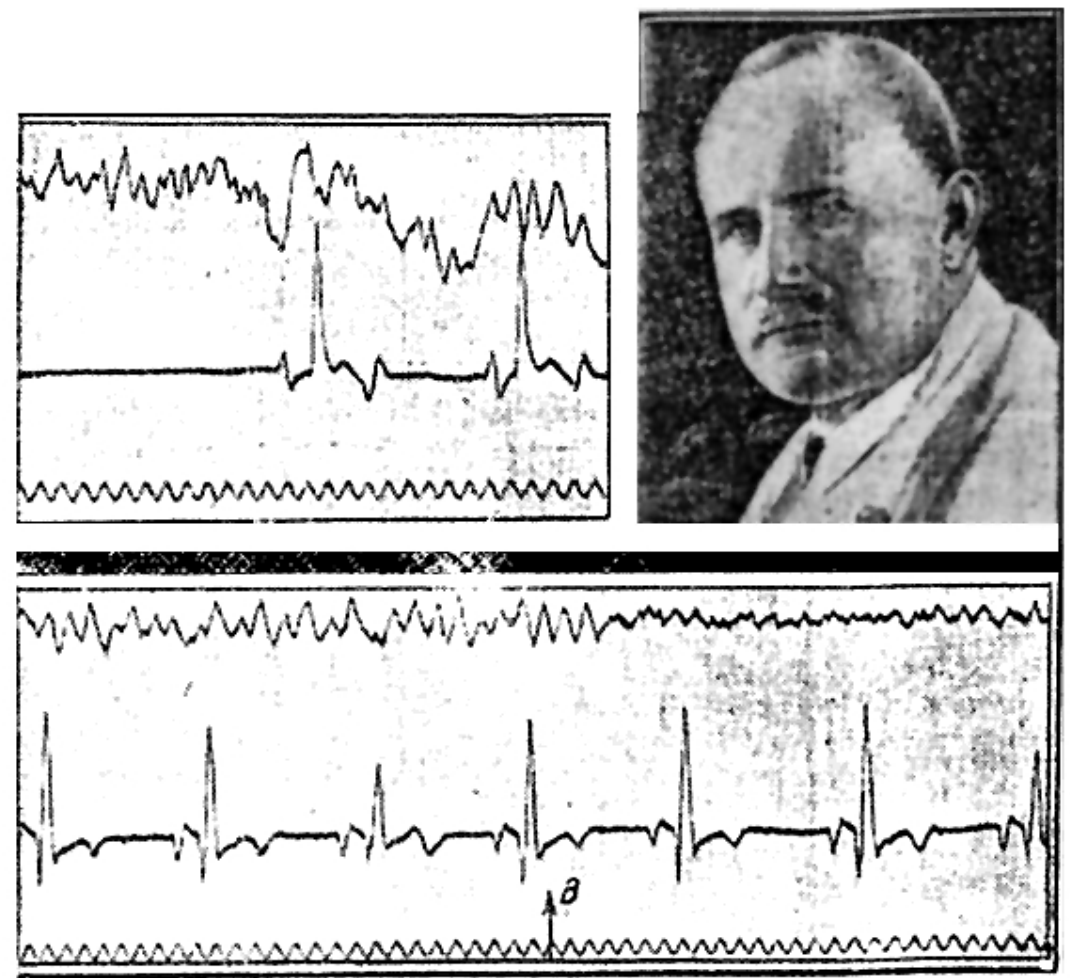

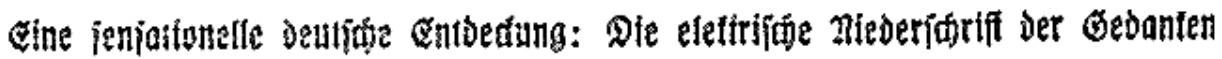

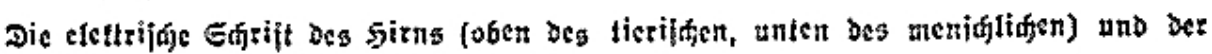 Entbedeะ \$rof. Dr. Sanis gerger}

Fig. 3. The emblematic arrangement of Berger's EEG in the daily press. From: BergischMärkische Zeitung, Elberfeld, August 3, 1930.

\section{Conclusions}

The development of electroencephalography did take the scientific world by surprise, and yet, the lay audience appeared quite ready to accept this device as a mind-reading machine that recorded, by means of electricity, some secret but meaningful signs from within the head. Notwithstanding the manifold material constraints and the demanding engineering sophistication that had to be mastered in such a delicate technique, it arrived at a cultural situation that was well accustomed to welcome electrical investigations into psychic life after experiencing various related interventions for more than a decade. Finkler's words express in a highly condensed way a cultural shift that I have aimed at reconstructing here. Bissky's diagnoscopy and Berger's electroencephalography shared common roots in traditional concepts of nineteenth-century neuroscience which, by the 1920s, had become either out-dated (phrenology) or old-fashioned (psychophysiological dualism); but nonetheless, these 
methods kindled widespread interest, both inside and outside academic science. Their conceptual backwardness notwithstanding, both methods demonstrated as forms of electrotechnical investigation a flexible adaptability to the contemporary issues at stake such as, in the case of diagnoscopy, the personality profiling for an economy under pressure and in desperate need of rational modernization, or, in the case of electroencephalography, mind reading by technological means. Electric technology provided new access to a realm of secret signs from the psyche, and in doing so, it contributed to gradually reconstructing psychic life in patterns of electrical signals. Finkler spelled out the utopia of this process, as it was already depicted in Kahn's popular visualizations of electrotechnical nervous systems. He forecast the emergence of a new technologically mediated honesty from the use of brain-machine interfaces for heart-to-heart communication. He speculated that electric technology and psychic activity would merge completely.

Bissky identified electrical signals as representations of the "physiological rhythm of our nervous system" and their diagnostic application for configuring personality profiles. Berger offered the means for inscribing electrical signals from the psyche onto paper for proving their true existence in a material world. Following the electrification of everyday life in Weimar Germany, electric technology steered psychophysiology into new forms for illuminating the soul. Electric currents, initially employed as the driving force for the experimental apparatuses, reconstructed psychic life until it emerged as driving force in the psychic apparatus. The development of electropsychology demonstrated the imaginative potential as well as the historical versatility of both, electricity and the psyche.

\section{Acknowledgments}

I thank Hannah Landecker, Skuli Sigurdsson, Anne Harrington, Fredrick Holmes, and the reviewers for discussions and helpful comments.

\section{References}

Adorno, Theodor W. 1996 [1944]. Dialektik der Aufklärung: Philosophische Fragmente. Gesammelte Schriften Bd. 3, third edition. Frankfurt/Main: Suhrkamp.

Arco, Georg Graf von and Alexander Herzberg. 1927: Die Bißkysche Diagnoskopie (Kleine Schriften zur Seelenforschung, Heft 17). Stuttgart: Julius Püttmann.

Asendorf, Christoph. 1993. Batteries of life: on the history of things and their perception in modernity. Berkeley: University of California Press.

Ash, Mitchell G. 1995. Gestalt psychology in German culture, 1890-1967, holism and the quest for objectivity. Cambridge: Cambridge University Press.

Baumgarten, Franciska. 1926. "Zur Frage der Elektrodiagnose seelischer Eigenschaften.” Zeitschrift für angewandte Psychologie 27:80-91.

Baumgarten, Franziska. 1928. Die Betriebseignungsprüfungen. Theorie und Praxis. München: Oldenbourg. Beltran, Alain. 1991. Le fée et la servante. La société française face à l'électricité XIXe-Xxe siècle. Paris: Belin.

Benn, Gottfried. [1926] 1985. "Medizinische Krise," in Gesammelte Prosa. Stuttgart: Klett-Cotta.

Berger, Hans. 1904-1907. Über die körperlichen Äußerungen psychischer Zustände. 2 parts and 2 atlases, Jena: Gustav Fischer.

Berger, Hans. 1921. Psychophysiologie in 12 Vorlesungen. Jena: Gustav Fischer. 
Berger, Hans. 1929. "Über das menschliche Elektrenkephalogramm [1. Mitteilung]." Archiv für Psychiatrie 87:527-570.

Berger, Hans. 1930. "Das Elektrenkephalogramm des Menschen." Medizinische Welt 4 (26):911-913.

Berger, Hans. 1937. "Physiologische Begleiterscheinungen psychischer Vorgänge." In Handbuch der Neurologie und Psychiatrie, Volume 2: Experimentelle Physiologie., edited by Oswald Bumke and Otfried Foerster, 492-526. Berlin: Springer.

Berger, Hans. 1940. Psyche. Jena: Gustav Fischer.

Berliner, B., A. Laqueur and E. Tobias. 1926. "Richtlinien der elektrophysikalischen Behandlungsmethoden für die ärztliche Praxis." Medizinische Klinik 22: 105-106, 144-145, 182-183, 223-224.

Binder, Beate. 1999. Elektrifizierung als Vision: Zur Symbolgeschichte einer Technik im Alltag. Tübingen: TübingerVereinigung für Volkskunde.

Bissky, Zachar. 1925. Die Diagnoskopie. Eine neue Methode zur medizinischen, psychologischen und forensischen Diagnostik. Karlsruhe and Berlin-Charlottenburg: Bios-Institut für praktische Menschenkunde.

Boening, Hans. 1941. "Hans Berger." Archiv für Psychiatrie und Nervenkrankheiten 114:17-24.

Borck, Cornelius. 2000. "Strom im Gehirn. Zur mehrfachen Erstbeschreibung elektrischer Hirnaktivität.” In Instrument - Experiment: Historische Studien, edited by Christoph Meinel, 118-127. Berlin, Diepholz: Verlag für Geschichte der Naturwissenschaften und Technik.

Borck, Cornelius. 2001: "Das Gehirn im Zeitbild: Populäre Neurophysiologie in der Weimarer Republik," in David Gugerli, Barbara Orland eds. Ganz normale Bilder: Zur visuellen Herstellung von Selbstverständlichkeiten im historischen Kontext, Zürich: Chronos (forthcoming).

Brain, Robert. 1996. "The graphic method: inscription, visualization, and measurement in nineteenthcentury science and culture." Ph.D. diss., University of California Los Angeles.

Brazier, Mary A. B. 1959. "The historical development of neurophysiology." In Handbook of Physiology I, I: Neurophysiology, edited by John Field, Horace W. Magoun, Victor E. Hall, 1-58. Washington D.C.: Amercian Physiological Society.

Brazier, Mary A. B. 1961. A history of the electrical activity of the brain: The first half-century. New York: Macmillan.

Brazier, Mary A. B. 1988. A history of neurophysiology in the $19^{\text {th }}$ century. New York: Raven Press.

Burrichter, Günther. 1983. "Die industrielle Psychotechnik und der durchsichtige Betrieb." In Rationalisierung 1984, edited by Staatliche Kunsthalle Berlin and Neue Gesellschaft für Bildende Kunst, 57-90. Berlin: Staatliche Kunsthalle.

Chadarevian, Soraya de. 1993. "Graphical method and discipline: self-recording instruments in nineteenth-century physiology." Studies in History and Philosophy of Science 24:267-291.

Cohn, Toby. 1898. Leitfaden der Elektrodiagnostik und Elektrotherapie für Praktiker und Studierende. Berlin: Karger.

Cooter, Roger. 1984. The cultural meaning of popular science: phrenology and the organization of consent in nineteenth-century Britain. Cambridge: Cambridge University Press.

Daston, Lorraine and Peter Galison. 1992. "The image of objectivity." Representations 40:81-128.

Finkler, Walter. 1930. "Die elektrische Schrift des Gehirns, Die Zickzackkurve der Menschenseele. Bahnbrechende Versuche eines deutschen Psychiaters." Neues Wiener Journal, July 4, p.7.

Fischgold, Henri. 1962. "Hans Berger et son temps." Actualités neurophysiologiques 4:197-221.

Foerster, Otfrid. 1926. "Zur operativen Behandlung der Epilepsie.” Deutsche Zeitschrift für Nervenheilkunde 89:137-147.

Foerster, Otfrid and H. Altenburger. 1935. "Elektrobiologische Vorgänge an der menschlichen Hirnrinde," Deutsche Zeitschrift für Nervenheilkunde 135:277-286.

Frank, Robert G. 1994. "Instruments, nerve action, and the all-or-none principle." Osiris 9:208-235.

Friedländer, Adolf A. 1926 “Die Bißkysche Diagnoskopie.” Die Umschau 30:1053-1057.

Friedländer, Adolf A. 1930. Telepathie und Hellsehen. Stuttgart: Enke.

Galison, Peter. 1998. "Judgment against objectivity." In Picturing science, producing art, edited by Caroline A. Jones and Peter Galison, 327-359. New York: Routledge. 
Gasser, Herbert S. and Joseph Erlanger. 1922. "A study of action currents of nerve with the cathode ray oscilloscope.” American Journal of Physiology 62:496-524.

Gernet, Rainer and Christa Habrich. 2000. Unter Strom, Zur Geschichte der Elektrotherapie, Ingolstadt: Medizinhistorisches Museum.

Giedion, Siegfried. 1969. Mechanization takes command: a contribution to anonymous history. New York: Norton.

Giese, Fritz: 1910. Die Lehre von den Gedankenwellen. Leipzig: Altmann.

Giese, Fritz. 1925. Girlkultur. Vergleiche zwischen amerikanischem und europäischem Rhythmus und Lebensgefühl. München: Delphin-Verlag.

Giese, Fritz. 1926. "Elektrodiagnostik des Characters" In Bericht über den neunten Kongreß für experimentelle Psychologie in München vom 21.-25. April 1925, 162. Jena: Gustav Fischer.

Giese, Fritz, ed. 1925-1934. Handbuch der Arbeitswissenschaft. Halle: Marhold.

Ginzberg, Raphael. 1949. "Three years with Hans Berger - a contribution to his biography.” Journal of the History Medicine and Allied Sciences 4:361-371.

Gloor, Pierre. 1969. "Hans Berger on the electroencephalogram of man. The fourteen original reports on the human electroencephalogram." In Electroencephalography and Clinical Neurophysiology, Suppl. 28.

Gloor, Pierre. 1974. "Hans Berger. Psychophysiology and the discovery of the human electroencephalogram." In Epilepsy. Proceedings of the Hans Berger Symposium, edited by Phillip Harris and Clifford Mawdsley, 354-373. Edinburgh: Livingstone.

Goldstein, Carolyn M. 1997. "From service to sales: home economics in light and power, 1920-1940." Technology and Culture 38:121-152.

Gradenwitz, Alfred. 1930. "Elektrische Gehirnströme.” Illustrierte Familienzeitschrift 62 (15):11.

Gradmann, Christoph. 1993. Historische Belletristik. Populäre historische Biographien in der Weimarer Republik. Frankfurt/Main: Campus.

Hagner Michael. 1997. Homo cerebralis. Der Wandel vom Seelenorgan zu Gehirn. Berlin: Berlin Verlag.

Harrington, Anne. 1987. Medicine, mind, and the double brain: a study in nineteenth-century thought. Princeton: Princeton University Press.

Harrington, Anne. 1996. Reenchanted science, holism in German culture from Wilhelm II to Hitler. Princeton: Princeton University Press.

Hayward, Rhodri. 2001. "The Tortoise and the Love-Machine: Grey Walter and the Politics of ElectroEncephalography" in this volume.

Herzberg, Alexander. 1929. "Methode und Ergebnisse des Berliner telepathischen Rundfunkversuches." Zeitschrift für angewandte Psychologie 31:66-106.

Hinrichs, Peter and Lothar Peters. 1976. Industrieller Friede? Arbeitswissenschaft und Rationalisierung in der Weimarer Republik. Köln: Pahl-Rugenstein.

Hubenstorf, Michael. 1993. "Elektrizität und Medizin." In Technik und Medizin, edited by Rolf Winau, 243-256. Düsseldorf: VDI.

Hughes, Thomas Parke. 1983. Networks of power: electrification in Western society, 1880-1930. Baltimore: Johns Hopkins University Press.

Hughes, Thomas Parke. 1989. American genesis: a century of invention and technological enthusiasm, 1870-1970. New York: Viking

Jaeger, Siegfried. 1985. "Zur Herausbildung von Praxisfeldern der Psychologie bis 1933." In Geschichte der deutschen Psychologie im 20. Jahrhundert, edited by Mitchell G. Asch and Ulfried Geuter, 83-113. Opladen: WestdeutscherVerlag.

Jung, Richard. 1963. "Hans Berger und die Entdeckung des EEG nach seinen Tagebüchern und Protokollen.” In Jenenser EEG-Symposium 30 Jahre Elektroenzephalographie, edited by R. Werner, 20-53. Berlin: VEB Verlag Volk und Gesundheit.

Kahn, Fritz. 1929. Das Leben des Menschen. Eine volkstümliche Anatomie, Biologie, Physiologie und Entwicklungsgeschichte des Menschen. Volume 4, Stuttgart: Franck'sche Verlagshandlung. 
Kapp, Ernst. 1877 Grundlinien einer Philosophie der Technik. Zur Entstehungsgeschichte der Cultur aus neuen Gesichtspunkten. Braunschweig: Westermann.

Karbowski, K. 1995. "Elektroenzephalographie und Epileptologie im 20. Jahrhundert." Schweizerische Rundschau für Medizin (Praxis) 84:1465-73.

Kittler, Friedrich 1992. "Die Welt des Symbolischen - eine Welt der Maschine.” In Draculas Vermächtnis. Technische Schriften, 58-80. Leipzig: Reclam.

Kolle, Kurt. 1956. "Hans Berger.” In Große Nervenärzte, edited by Kurt Kolle, 1-6. Stuttgart: Thieme.

Kornmüller, Alois, E. 1938. "Die Untersuchung über die bioelektrischen Potentialschwankungen der Hirnrindenfelder im Dienste der Klinik.” Münchener Medizinische Wochenschrift 85:1856-1860.

Lawrence, Christopher and George Weisz, eds. 1998. Greater than the parts, holism in biomedicine, 1920-1950. Oxford: Oxford University Press.

Lehmann, Alfred. $1899+$ 1901. Die körperlichen Äusserungen psychischer Zustände, I. Teil: Plethysmographische Untersuchungen, II. Teil: Die physischen Äquivalente der Bewusstseinerscheinungen. Leipzig: Bendixen.

Lenoir, Timothy. 1994. "Helmholtz and the materialities of communication." Osiris 9:185-207.

Lück, Helmut E. and Wolfgang Rechtien. 1994. "Klinisch-psychologische Interpretationen historischer Dokumente. Ein forschungsmethodische Studie zum Abschiedsbrief von Robert Werner Schulte." Psychologie und Geschichte 6:180-199.

Lück, Helmut E. 1994. “'. . . Und halte Lust und Leid und Leben auf meiner ausgestreckten Hand.” Zu Leben und Werk des Psychologen Robert Werner Schulte” In Arbeiten zur Psychologiegeschichte, edited by Horst Gundlach, 39-48. Göttingen: Hogrefe.

Ludwig, Emil. 1926. "Die Durchleuchtung der Seele.” Berliner Illustrirte Zeitung 34(10):299-306.

McLuhan, Marshall. 1964. Understanding media: the extensions of man. New York: McGraw-Hill.

Millett, David and Cornelius Borck. 1999. "Navigating the sea of brain waves: electroencephalography in the 1930 and 1940s." Abstracts of the Meeting of the History of Science Society, 123-124. Philadelphia.

Millett, David. 2001. "Wiring the brain: from the excitable cortex to the EEG, 1870-1940." Ph.D. diss. University of Chicago.

Möhringer, J. 1927: "Kurpfuscherunfug mit den rundfunkstörenden Hochfrequenzapparaten." Der Deutsche Rundfunk 5(37):25-57.

Morus, Iwan Rhys. 1998. Frankenstein's children: Electricity, exhibition, and experiment in early nineteenth century London. Princeton: Princeton University Press.

Mosse, George L. 1992. Jüdische Intellektuelle in Deutschland zwischen Religion und Nationalismus. Frankfurt/Main: Campus.

Münsterberg, Hugo. 1914. Grundzüge der Psychotechnik. Leipzig: Barth.

Nolan, Mary. 1994. Visions of modernity: American business and the modernization of Germany. Oxford: Oxford University Press.

Osietzki, Maria. 1996. "Weiblichkeitsallegorien der Elektrizität als 'Wunschmaschinen'." Technikgeschichte 63:47-70.

Pancaldi, Giuliano and Paola Bertucci. 2001. Electric bodies: Episodes in the history of medical electricity. Bologna: Centro Internazionale per la Storia delle Università e della Scienza.

Paulcke, Wilhelm. 1925. "Bericht über die elektrodiagnostische Untersuchungsmethode von Dr. Bissky." In Die Diagnoskopie, Zachar Bissky, 7-14. Karlsruhe and Berlin-Charlottenburg: Bios-Institut für praktische Menschenkunde.

Plitzner, Klaus. 1998. "'The amazing magic that live in a wire'. Eine Gegenüberstellung der Welt der Elektrizität in der deutschen 'Gartenlaube' und im amerikanischen 'Ladies' Home Journal.' In Elektrizität in der Geistesgeschichte, edited by Klaus Plitzner, 87-105. Bassum: GNT-Verlag.

Prawdicz-Neminski, Wladimir W. 1925. "Zur Kenntnis der elektrischen und der Innervationsvorgänge in den funktionellen Elementen und Geweben des tierischen Organismus. Electrocerebrogramm der Säugetiere." Pflüger's Archiv 209:362-382.

Rabinbach, Anson. 1990. The human motor: energy, fatigue, and the origins of modernity. Berkeley: University of California Press. 
Rahner, Richard. 1926. "Die fardokutane medizinische Elektrodiagnostik - Rahner." Psychologie und Medizin 1:237-247.

Richter, Jochen. 1981. "Die Entdeckungsgeschichte der Elektroenzephalographie und die Entwicklung ihrer technischen Voraussetzungen." Deutsches Gesundheitswesen 36:1307-1311, 1346-1350, 1432-1436.

Risse, Guenter B. 1976. "Vocational guidance during the depression: phrenology versus applied psychology." Journal of the History of the Behavioral Sciences 12:130-140.

Rosner, Lisa. 1988. "The professional context of electrotherapeutics." Journal of the History of Medicine and Allied Sciences 43:64-82.

Rowbottom, Margaret and Charles Susskind. 1984. Electricity and medicine: history of their interaction. San Francisco: San Francisco Press.

Sachse, Carola. 1987. Betriebliche Sozialpolitik als Familienpolitik in der Weimarer Republik und im Nationalsozialismus. Hamburg: Hamburger Institut für Sozialforschung.

Schrenk, Martin. 1970. "Hans Bergers Idee von der 'psychischen Idee'.” Nervenarzt 41:263-279.

Schulte, Robert Werner. 1925. "Über Elektrodiagnose seelischer Eigenschaften.” Psychologie und Medizin 1:62-94.

Schulte, Robert Werner. 1925/26. "Experimental-psychologische Untersuchungen zur Prüfung der Kontrollbedingungen bei okkultistischen Dunkelsitzungen." Zeitschrift für kritischen Okkultismus $1: 248-262$.

Schulte, Robert Werner. 1926. "Die Eignung zum Sport- und Verkehrsflieger." Die Schönheit 22:519-541.

Schulte, Robert Werner. 1928. Stolz und Wehmut. Lieder der Liebe. Berlin: Gustav Eppenheim.

Schulte, Walter. 1959. "Hans Berger: Ein Lebensbild des Entdeckers des Elektroenzephalogramms." Münchner medizinische Wochenschrift 101:977-980.

Senior, John E. 1994. "Rationalising electrotherapy in neurology, 1860-1920.” Ph.D. diss., Linacre College, University of Oxford.

Smith, Roger. 2001. "Representations of Mind: British Scientific Opinion, c. 1930-1950" in this volume.

Sommer, Robert. 1928. "Nachprüfung der elektrodiagnostischen Methoden von Dr. Rahner und Dr. Bissky.” In Bericht über X. Kongreß für experimentelle Psychologie 1927 in Bonn, 167-169. Jena: Gustav Fischer.

Steinhausen, Wilhelm. 1928. "Der derzeitige Stand der Elektrophysiologie." In Neuere Erfahrungen auf dem Gebiet der medizinischen Elektrizitätslehre mit Ausschluß der Röntgenlehre, edited by Ludwig Boruttau, 45-144. Leipzig: Thieme.

Verweyen, Johannes M. 1926. "Die Elektro-Diagnoskopie Z. Bissky." In Beruf und Charakter, edited by Max von Kreusch, 61-64. Berlin: Verlag Kreusch.

Walter, Fritz K. 1927. "Über die Elektrodiagnose seelischer Eigenschaften ('Diagnoskopie') nach Bißky. Eine kritische Besprechung." Jahrbuch der Charakterologie 4:297-324.

Wieczorek, V. 1991. “In memoriam Hans Berger (1873-1941) Entdecker des Elektroenzephalogramms des Menschen." Nervenarzt 62:457-459.

Wohlmuth, A.G. 1925. Elektro-galvanische Heilkunde. Ein Handbuch zum Heilgebrauch galvanischen Stromes für Kranke und Gesunde, Furtwangen/Schwarzwald: Wohlmuth.

Young, Robert M. 1990. Mind, brain, and adaptation in the nineteenth century: cerebral localization and its biological context from Gall to Ferrier. Oxford: Oxford University Press. 